\title{
EPB tunnelling in deltaic deposits: observations of ground movements
}

A. Gens, A. Di Mariano \& M.T. Yubero, Department of Geotechnical Engineering and Geosciences, Technical University of Catalonia (UPC), Barcelona, Spain

\section{INTRODUCTION}

A new Metro line, named Line 9, is currently under construction in the Barcelona metropolitan area (Di Mariano et al., 2007; Gens et al., 2006). It has a total length of $47.8 \mathrm{~km}$, out of which nearly $44 \mathrm{~km}$ correspond to tunnelling.

The poster refers to the excavation of the Line 9 between Mas Blau Station and Barcelona airport. This $4.33 \mathrm{~km}$-long section of the Line, are completely excavated in soft deltaic deposits and crosses an urban area close to some sensitive structures.

\section{GROUND CONDITIONS}

The geology comprises materials of Quaternary age, belonging to the deltaic deposits of the Llobregat River, which constitute, at the larger scale, a rather homogeneous geological profile. The water table is nearly horizontal and located 0 $1 \mathrm{~m}$ above sea level.

Except in the proximity of the Stations, the ground cover of the tunnel is about $16 \mathrm{~m}$,

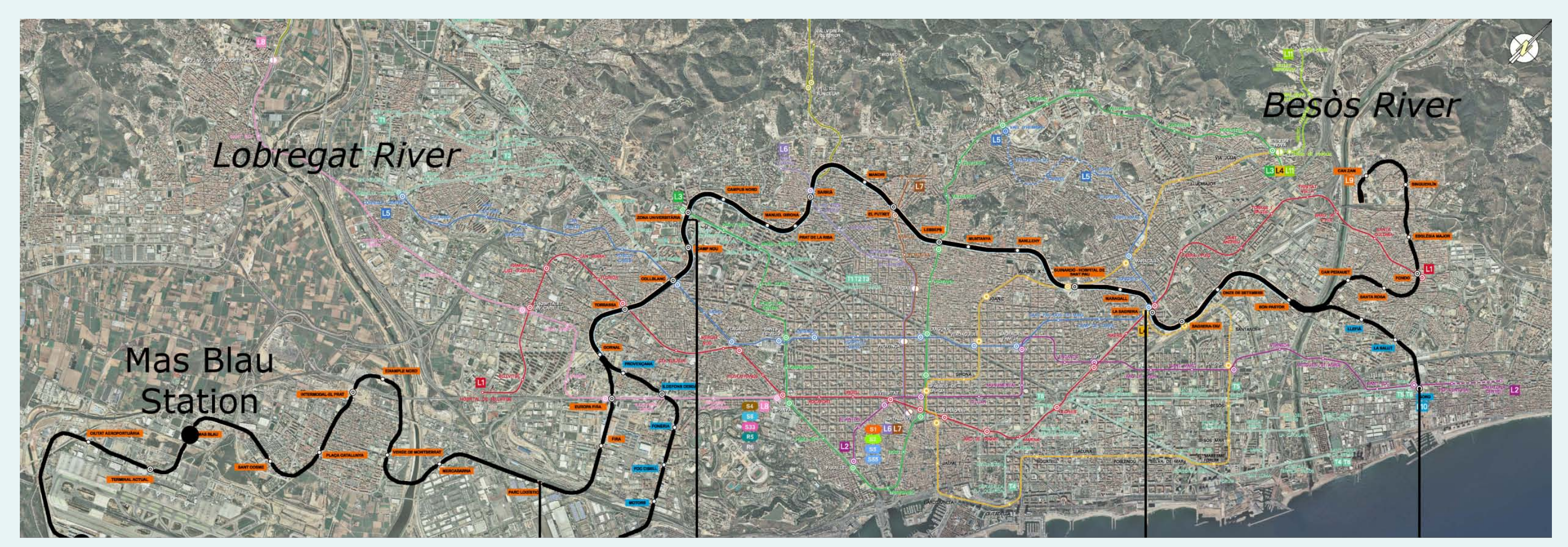
with a cover/diameter (C/D) ratio of approximately 1.7 .

Barcelona

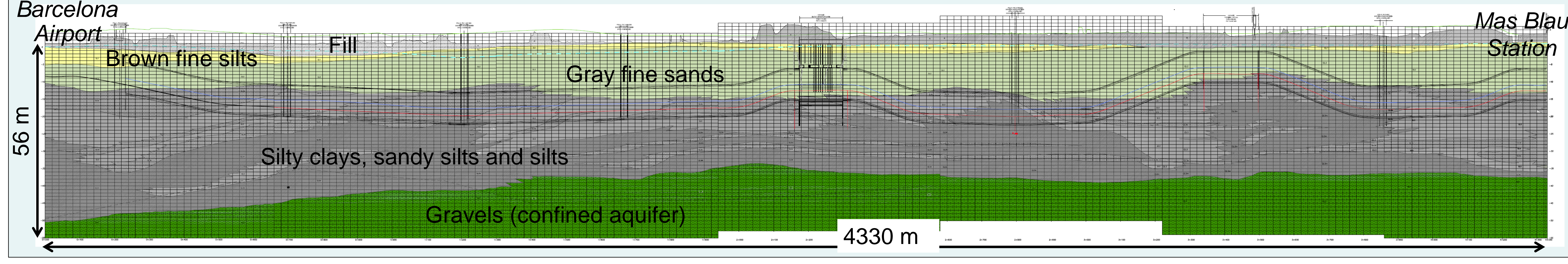

\section{TUNNEL EXCAVATION}

Tunnelling was performed using a earth-pressure-balance (EPB) boring machine. The overall average advance rate along the route was $28.5 \mathrm{~m} / \mathrm{day}$. During the excavation of this part of the Line, bentonite was systematically injected in the over-excavated annulus around the shield and the tail void was always grouted simultaneously to the EPB shield advance, in order to improve ground movement control (Wongsaroj et al., 2006).

\section{GROUND MOVEMENT OBSERVATIONS}

Field observations indicated that the parameter $\mathrm{K}$ assumes an average value of approximately 0.50 at ground level. Data confirms that $\mathrm{K}$ appears to increase with depth.

\begin{tabular}{|c|c|c|c|c|c|c|}
\hline \multirow{2}{*}{$\begin{array}{l}\text { Reference } \\
\text { Section } \\
\text { Chainage }\end{array}$} & \multirow{2}{*}{$\begin{array}{c}\text { Depth of } \\
\text { tunnel } \\
\text { axis } \\
H_{0} \\
\end{array}$} & \multirow{2}{*}{$\begin{array}{c}\text { Volume } \\
\text { loss } \\
\text { VI }\end{array}$} & \multicolumn{2}{|c|}{$\begin{array}{l}\text { Surface } \\
\text { settlement } \\
\text { trough }\end{array}$} & \multicolumn{2}{|c|}{$\begin{array}{l}\text { Settlement } \\
\text { trough at } \\
9.5 \mathrm{~m} \text { depth }\end{array}$} \\
\hline & & & $K$ & $i$ & $K_{\text {sub }}{ }^{*}$ & $i_{\text {sub }}{ }^{*}$ \\
\hline $\mathrm{m}$ & $\mathrm{m}$ & $(\%)$ & - & $\mathrm{m}$ & - & $\mathrm{m}$ \\
\hline $4+150$ & 18.7 & 0.22 & 0.51 & 9.5 & 0.59 & 5.4 \\
\hline $4+000$ & 20.2 & 0.68 & 0.42 & 8.5 & 0.55 & 5.9 \\
\hline $2+750$ & 21.4 & 0.50 & 0.52 & 11.1 & 0.70 & 8.3 \\
\hline
\end{tabular}
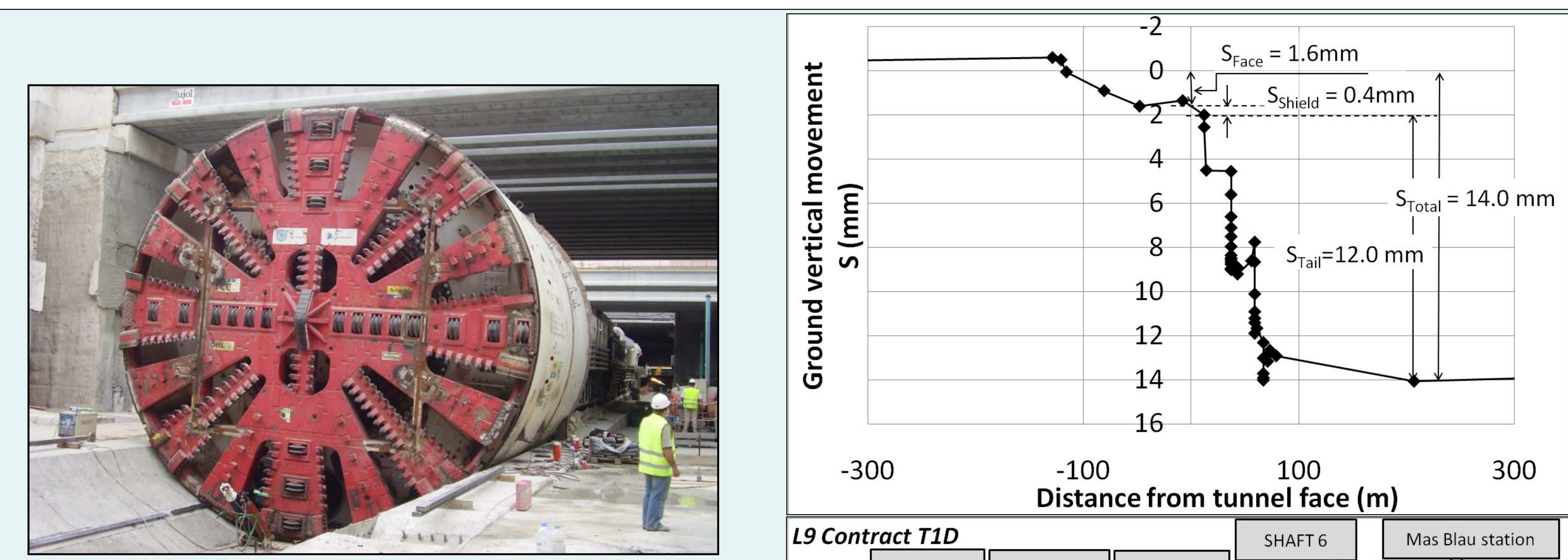

The computed volume loss along the route, after the passage of the EPB beyond the zone of influence, generally lies between 0.0 and $0.6 \%$. Most of the larger volume losses are associated with the entrance or exit from shafts used for maintenance purposes.

\section{INFLUENCE OF EPB OPERATING PRESSURES ON VOLUME LOSS}

When face pressures are in the range $48-78 \%$ of the overburden pressure, the face volume loss is maintained well inside the $\pm 0.2 \%$ range.

Bentonite pressures in the range $33-74 \%$ of the overburden pressure keep shield volume loss below $0.3 \%$ and generally much lower.

The volume loss due to the closure of the tail void represents the greatest percentage of the total volume loss. Despite the large scatter in the data, there appears to be a rough tendency of the tail volume loss to decrease as the grouting pressure ratio increases.

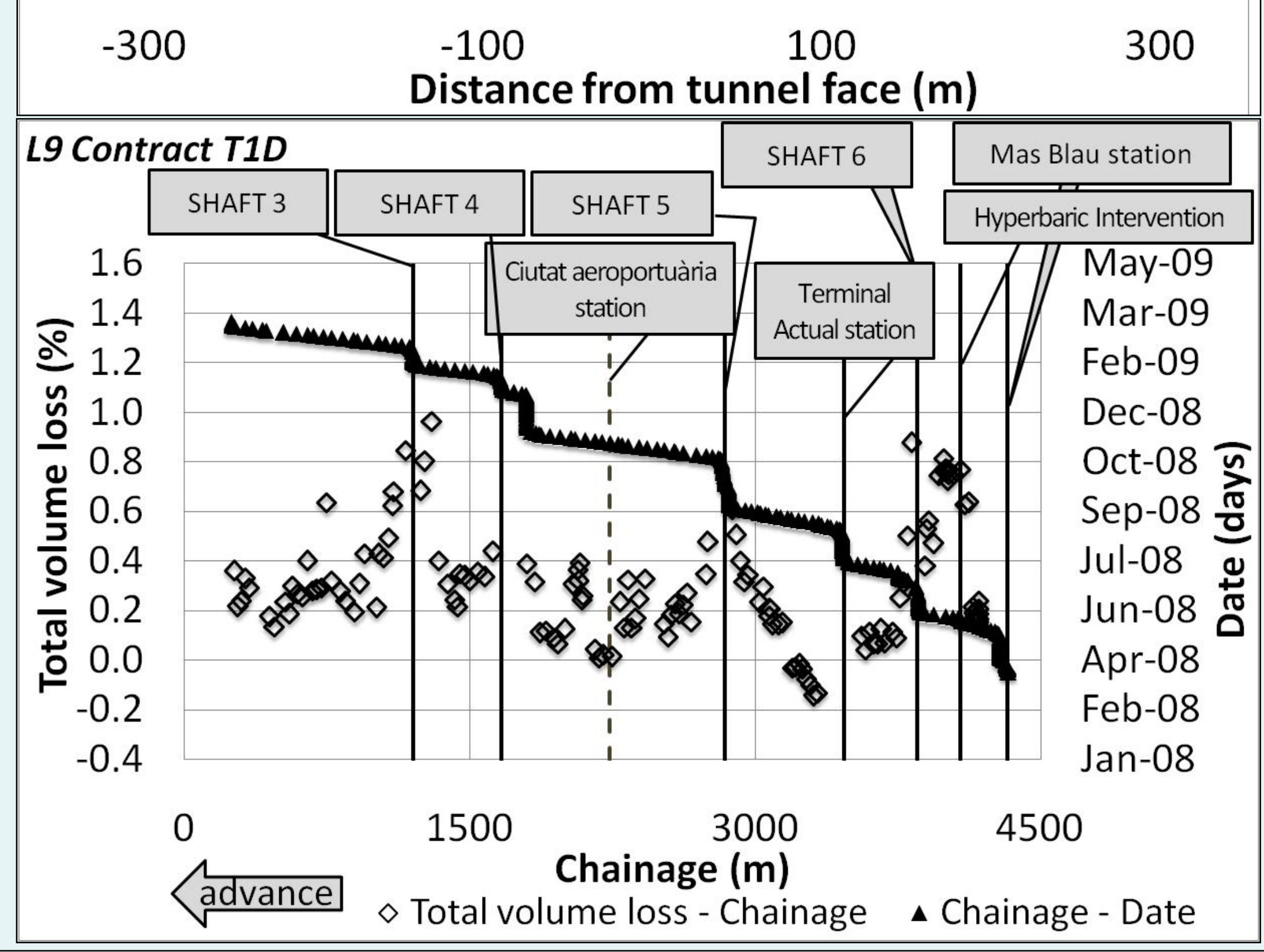

\section{CONCLUSIONS}

The face settlements and volume loss are always quite small and sometimes even negative, indicating heave ahead of the EPB machine. The shield volume loss is more variable but also normally small. Most of the volume loss is associated with the closure of the gap after the passage of the shield. In spite of a large scatter of the data, there appears to be a correlation between the grouting pressures used and the tail volume loss.

The volume loss observed in the majority of cases is quite limited and the range of pressures adopted has been successful in reducing settlements to quite acceptable values in spite of the poor geotechnical characteristics of the excavated ground.

\section{REFERENCES}

Di Mariano A., Gesto J.M., Gens A. \& H. Schwarz (2007). Ground deformation and mitigating measures associated with the excavation of a new Metro line. Proc. of the 14th ECSMGE: 1901-1906, Madrid.

Gens A., Di Mariano A., Gesto J.M. \& H. Schwarz (2006). Ground movement control in the construction of a new metro line in Barcelona. Geotechnical Aspects of Underground Construction in Soft Ground: 389-395. Taylor \& Francis eds.

Wongsaroj J., Borghi F.X., Soga K., Mair R.J., Sugiyama T., Hagiwara T. \& Bowers K.H. (2006). Effect of TBM driving parameters on ground surface movements: Channel Tunnel Rail Link Contract 220. Geotechnical Aspects of Underground Construction in Soft Ground: 335-341. Taylor \& Francis eds. 